
Michael PERCIALI

Discuții pe marginea diplomelor de la

Facultatea de Arhitectură, Sesiunea

martie 2019 UAUIM

Discussions on the diploma projects from the Faculty of Architecture,

2019 March (Diploma Session)

UAUIM 


\section{Discuții pe marginea diplomelor de la \\ Facultatea de Arhitectură, \\ Sesiunea martie 2019 \\ UAUIM}

\author{
Discussions on the \\ diploma projects from the \\ Faculty of Architecture, \\ 2019 March (Diploma \\ Session) UAUIM
}

\section{rezumat}

Este a 3-a invitație și al 2 lea articol ce îl scriu în acest subiect - toate datorate inițiativei Dlui Președinte E.B.Popescu de a avea printre criticii școlii și câțiva invitați care practică meseria în afara țării. Tot ce scriu sunt păreri personale formate în cei 45 de ani de practica globală a meseriei, plus scurte activități academice atât la Mincu cât și în USA. Practica de arhitectură în USA este reglementată de Statul în care practici - al meu fiind New Jersey (NJ) care este foarte strict în eliberarea și reînnoirea dreptului de semnătură - astea fiind spuse, cei care practicăm în NJ participăm anual la numeroase evenimente educaționale în materie, multe din ele fiind în cadrul scolilor de arhitectură - în cazul meu Princeton Univ. Astfel, legătura între practică și academia atât de necesară profesiei noastre este reală în cazul meu. Găsesc că inițiativa Dlui Președinte în această direcție este bună studenților de la UAUIM, în sensul că îi expune la experiența de a fi evaluați și din punct de vedere global, nu numai local. Discuția de merit sau nu a acestui sistem este lungă și complexă, o voi aborda cu altă ocazie.

cuvinte cheie

arhitectură, UAUIM, diploma, școala de arhitectură abstract

It is the third invitation, and second invitation to write this article - all due to the initiative of President E.B. Popescu to have among the critics of the school and some guests who practice the profession abroad. All I write are personal opinions formed during the 45 years of the global practice of the profession plus short academic activities both in Mincu and in the USA. The practice of architecture in the USA is regulated by the State where you practice - mine being New Jersey (NJ) - which is very strict in issuing and renewing the right of signature - that being said, those who practice in NJ participate annually in numerous educational events in matter, many of them being in architecture schools - in my case Princeton Univ. Thus, the connection between the practice and the academy so necessary to our profession is real in my case. I find that the initiative of the President in this direction is good for the students of UAUIM, in that it exposes them to the experience of being evaluated and from a global point of view, not only locally. The discussion of merit or not of this system is long and complex, I will approach it on another occasion.

keywords

architecture, UAUIM, diploma, school of architecture
Michael PERCIALI

percimx@gmail.com

MA, AIA Emeritus, NCARB, OAR, LEED, GPRO Arhitect, Profesor Invitat UAUIM, Sesiunea de Diplome Martie 2019 Facultatea de Arhitectură UAUIM Architect, Visiting Professor at UAUIM, 2019 March Session Diploma projects - Faculty of Architecture UAUIM

Departament Sinteza Proiectării de Arhitectură Facultatea de Arhitectură Universitatea de Arhitectură și Urbanism Ion Mincu UAUIM București Synthesis of Architectural Design Department (SP) Faculty of Architecture Ion Mincu University of Architecture and Urbanism
UAUIM Bucharest 
Cu întârziere scriu, dar vă asigur că amintirile de la sesiunea de diplome martie 2019 îmi sunt încă vii în memorie. Este a 3-a invitație și al 2 lea articol ce îl scriu în acest subiect - toate datorate initiativei Dlui Președinte E.B.Popescu de a avea printre criticii școlii și câțiva invitați care practică meseria în afara țării. Tot ce scriu sunt păreri personale formate în cei 45 de ani de practica globală a meseriei plus scurte activități academice atât la Mincu cât și în USA. Practica de arhitectură în USA este reglementată de Statul în care practici - al meu fiind New Jersey (NJ) - care este foarte strict în eliberarea și reînnoirea dreptului de semnătură - astea fiind spuse, cei care practicăm în NJ participăm anual la numeroase evenimente educaționale în materie, multe din ele fiind în cadrul scolilor de arhitectură în cazul meu Princeton Univ. Astfel, legătura între practică și academia atât de necesară profesiei noastre este reală în cazul meu.

Găsesc că inițiativa Dlui Președinte în această direcție este bună studenților de la UAUIM, în sensul că îi expune la experiența de a fi evaluați și din punct de vedere global, nu numai local. Discuția de merit sau nu a acestui sistem este lungă și complexă, o voi aborda cu altă ocazie.

Real este că practica noastră este globală de cel puțin 30 de ani și istoria ne amintește că nu este un fenomen unic secolului 20-21. Clar în antichitate forma de arhitectură și materialele / sistemele de construcții au circulat deșigur într-o zonă restrânsă din motive evidente.

Parcurgând firul istoriei, teritoriul s-a lărgit în Evul Mediu cuprinzând mai toată Europa civilizată, apoi revoluția industrială a lărgit zona de circulație a arhitecturii peste Ocean, în modernitate s-a răspândit pe tot continentul American, în perioada post-modernitate ne-am lărgit cuprinzând mai toate continentele $\mathrm{cu}$ prezențe remarcabile în multe metropole ale lumii. Pot spune că la un înalt nive profesional atins, granițe nu mai există în meseria noastră.

Practicieni talentați din diferite țări și cultur proiecteză și construiesc în locuri îndepărtate și geografic și cultural de formarea lor de "acasă" asta este ce ne-a adus globalizarea. Cel mai recent văd că practicanți talentați din țările Africii încep și ei să pătrundă cu lucrări majore de arhitectură în unele orașe greu de penetrat datorită calității și originalității architecturii promovate, cum ar fi USA, și West Europe. Dar reversul medaliei există și este de ani recunoscut și conturat că există un efect negativ în societăți, în special în probleme de mediu, de consumatorism, inegalități economico-sociale si de identitate culturală pierdută - asta fiind o discutie lungă pe care sper să o avem cu altă ocazie. Sccoala Ion Mincu - după cum văd eu - navighează între o tradiție puternic regională - istorico-culturală bogată - și limbajul contemporan global al arhitecturii de azi.

In diplomele discutate mai jos, sporadic se ating elemente care preocupă întreaga omenire, cum ar fi schimbarea climaterică, securitate și siguranța în exploatare a consumatorilor și bunurilor, aglomerările urbane, costul ridicat al energiei, problema foarte dificilă și costisitoare a transportu populației, acessibilitatea celor cu disabilități, conservarea energiei, pe lângă adoptarea unui limbaj care să atragă business, și să placă beneficiarilor care plătesc investiția pentru un branding și un profit specific ca și a celor ce o vor folosi și opera. Desigur proiectele trebuie să respecte și cerințele organelor locale de avizare și control pe teritoriul unde se construieste. Vedem 
clar că numărul de cerințe este mult mai ridicat acum decât cu decenii în urmă, astea venind peste termenele scurte de executare, bugetele mici alocate și competiția globală în care profesăm. Să nu ne mirăm că aceste bariere cern numărul de absolvenți doritori să practice la un număr mic adică numai cei talentați și pasionați în școală vor putea naviga în acestă nouă piață.

Nu de neglijat este și faptul dovedit cât de important proiectant - școala unde petrece mulți ani literalmente zile și nopți, orașul unde trăiește și prin care circulă zilnic. Este cunoscută formarea radical modernistă a majorității absolvenților de la IIT (Illinois Institue of Technology) din Chicago în urma puternicei amprente lăsată de Mies van der Rohe, dacă o comparăm cu o formare poetic modernistă a Școlilor din Estul SUA (NY, Philadephia) influențate de teoriticieni / practicanți post moderniști (Luis Kahn, Robert Venturi, Michael Graves etc.)

Recent este discutată și acceptată în USA noțiunea că "authorship" - ul în profesia de azi dispare din cauze legate de tehnologia robotică de proiectare și execuție, ca și cea a globalizării noțiunii climaterice, a codurilor internațional acceptate și a limbajului global de exprimare, unde autorii devin ne-relevanți, comanda socială luându-le locul că autoritate în deciziile de proiectare.

Cum adresează (sau nu adresează) diplomele din Martie 2019 aceste aspecte de mai sus? Recitind articolul din revista Arhitext 3/2018 revăd calități / lipsuri similare în 2019 cu cele din 2018. Nu voi repeta nimic din articolul precedent - el există și poate fi consultat la nevoie, deci care sunt elementele noi în 2019 pe următoarele categorii:

(Nu sunt listate în anumită ordine, toate sunt egal importante).
- Răspunsul la tema de proiect

- Integrarea în site - contextul

- Economice - contribuția ce o poate avea (sau nu avea) investiția la ridicarea bunăstării în zona aleasă.

- Siguranța în exploatare - coduri în construcție

- Partea structurală, partea mecanică - electrică, coordonarea între discipline

- Estetica și calitatea vieții oferită ocupanților

- Pași spre protejarea resurselor naturale și combaterea cauzelor care duc la schimbări climaterice

- Desigur prezentarea studentului, verbală, vizuală cât și prezența lui / ei fizică în fața juriului.

Mai este o categorie pe care o pomenesc pentru că există în lume și are rolul ei - anume, talentul nostru în advocacy pentru a susține politic subiecte ce țin de meserie, cu ramificații în campaniile de alegeri a celor ce pot sprijini sau împiedica obiectivele noastre - dar cred că nu este încă cazul în România - poate mă însel.

Din grupul celor 16 diplome prezentate pentru judecată și notare, găsesc o consistență în calitatea (sau lipsa ei) între studenți, nimic nu se ridică peste medie, și nici sub medie nu am observat. Ca o trăsătură comună, volumul de muncă depus este consistent enorm la majoritatea prezentărilor văzute - munca de proiectare este într-adevăr foarte laborioasă, dar de multe ori auzim în meseria noastră sloganul: "work smart not hard" - și vă asigur că este real și foarte indicat în practica americană. Se referă în special la a atinge elementele esențiale în proiectare, cele de idee, de mesaj, de inovație, lăsând partea de grafică și de modelare roboților să o facă. 
Diplomele prezentate pot fi considerate ca fiind în faza de "BoD" adică "basis of design", ceea ce reprezintă cca $30 \%$ din efortul total de finalizare a unui proiect de execuție. Nu este nevoie de mai mult la diplome, nevoia este că la sfârșitul unui BoD toate deciziile de proiectare să fie corect / complet luate referitor la toți parametrii de proiectare, de la temă, la site, la coduri, costuri, modul de construcție, funcționalitate, coordonare cu ingineria, estetică. Acest BoD în cele mai multe cazuri se dezvoltă înspre design development / contract documents în alte birouri de proiectare, în alte țări și pe alte continente, continuitatea ideilor se poate întrerupe pe parcurs, de aceea BoD - ul trebuie să fie cât se poate de complet, fără ambiguități. Dacă vă întrebați de ce acest sistem? - Sunt motive economice și politice complexe care nu fac parte din acest articol.

Ascultând părerile altor profesori invitați din străinătate la acestă judecată, surprins aud păreri asemănătoare între noi, care țintesc îmbunătățirea diplomelor - cum ar fi: frecvența mai deasă a corecturilor de proiect mult înainte de a desena prima linie pe CAD.

Profesorii străini, în jurul unei mese de lunch și în prezența Dlui Decan și a altor cadre didactice de la UAUIM au afirmat că sunt dispuși să facă "corectură online" pe parcursul dezvoltării proiectului de diplomă. De comun acord s-a constatat că există la UAUIM forma de "internet review and discussion" cum ar fi UAUIM sponsored websites pe grupe de studenți, administrate de diploma advisers, și accesul pe acel site se poate da acelor consultanți care se oferă voluntar să facă verificări de proiecte pe parcursul perioadei alocate diplomelor. Nu sunt informat dacă s-a implementat acest process, și cu ce rezultate, desigur mă număr printre aceia care voluntariază la acest efort.

Fără a reproiecta proiectul discutat, cam ce vedem în continutul diplomelor pe hârtie, pe materialul "handout" și ce auzim de la studenții - viitori arhitecți:

Adresări pe marginea diplomelor văzute:

- Deși temele artistic/cultural/educative abundă la punctul la care te potii întreba "unde sunt tratate nevoile reale curente din țară? - apar și teme de reabilitări ale unor edificii și / sau zone existente uitate. Ele sunt prezente în multe diplome și în acest an - un lucru meritoriu care atinge valențe economice, ecologice, culturale de prezervare trecutului valoros din țară. Mesaje de gândire sustenabilă, de revitalizare / ridicare a zonelor degradate mult dorite sunt prezente și rămân apreciate în condițiile actuale din România. De cele mai multe ori, scara de abordare a volumetriei proiectului este adecvată cu tema, ș cu locația aleasă, argumentația deciziilor formale și funcționale de cele mai multe ori o găsesc bine conturată. La fel de bine găsesc și abilitatea unora de a integra limbajul vernacular valoros al arhitecturii naționale țărănești cu temele, formele și limbajul contemporan de arhitectură.

- Mai aștept să apară în diplomele viitoare și abordări/ investigații de tematici globale, deja reale în afara granițelor, dar cu posibile repercursiuni și în țară - acum sau mai târziu - dar nu vor trece neobservate. Ma refer la subiecte globale umanitare legate de migrații, schimbări climaterice cu repercursiuni economice, sărăcirea populației și lipsa de oportunități, lipsa de adapost adecvat, criza energetică într-o lume în care accesul la energie cu preț convenabil este cheia în 
dezvoltare, consumatorism excesiv și poluare, accesul - sau lipsa lui - la information technology pe plan global. Aceste subiecte și altele asemănătoare ar trebui să fie susţinute cu referiri la reale progrese pe plan mondial care încearcă să răspundă problemelor sociale de azi, rezolvări cum ar fi: Smart City, Net Zero buildings, Live, work, play comunities, etc.

- Recunoscut și acceptat este faptul că ideile de mai sus nu sunt suficiente pentru reușita unui proiect - ele sunt un bun început care trebuie continuat cu rezolvări mai puțin vizibile dar la fel sau mai importante decât mesajul proiectului. Ma refer aici la mica atenție acordată în diplomele văzute codurilor în construcții pentru siguranța în folosință, cum ar fi căile de evacuare, separarea în compărtimente rezistente la fum / foc, - în general cam la ce se referă P118 și nu trebuie să insist pe importanța lui în avizarea unui proiect. Prin reabilitarea unui edificiu al secolului 18, 19, partea de siguranță în expolatare trebuie total refacută la normele de azi - nu poate să rămână cum o găsim în acele perioade.

- La fel de importantă este și respectarea standardelor de accessibilitate a celor cu disabilități - poate încă nu este o legislație în acestă privință în România, dar este în mai toată lumea și își vă găsi și în România locul pe motive economico-politice în cadrul EU, asta făcând subiectul altei discuții. Mă refer aici în special la cei ce au ales să trateze programe pentru persoane vârstnice unde acesibilitatea totală este esențial de atins, sau mai elegant spus, "universal design pentru universal people".

- La fel pot spune că lipsa aprofundării considerațiilor inginerești în construcții cum ar fi partea mecanică și cea electrică, încă există. Lifturile au nevoie de o cameră mecanică a pompelor - dacă (liftul) este hidraulic, sau una a motoarelor electrice în penthouse dacă (lifturile) sunt pe tracțiune cabluri.

- Alternative energy - (wind turbine, geothermal) apare în diplome, dar nu este concludent dezvoltată cu calcule economice de ROI (return of investment) care să dovedescă beneficiarului că sunt o investiție bună oricărui finanțator, ROI fiind singura cea mai importantă argumentație în favoarea investițiilor în energii alternative.

- Panourile solare par uitate deși tehnologia lor avansează an de an în timp ce costul lor coboară. Accidental și izolat observ conceptul de "green roof"- care are multiple efecte pozitive asupra mediului în special la orașe, dar la fel, fără o explicație convingătoare asupra beneficiului adus vs. cost.

- Din punct de vedere formalist al tratării clădirilor observ cu plăcere că metoda de proiectare "inside -out" spre deosebire de "outside-in" sunt predominante în mai toate diplomele. Acestea arată claritate în gândirea studentului - viitor arhitect, și recunoașterea că există un program, un sistem structural, un site, un buget, care sunt prioritare formei de exprimare.

- Dar când ne gândim la buget, la costul unui asemenea edificiu putem fi surprinși de unele selecții de sisteme considerate scumpe - și nu la scara proiectului, - cum ar fi: spații prea generoase pentru circulații, parcarea etajată care necesită lifturi pentru automobile, subsoluri mecanice, pentru utilități și subsoluiri garaje în zone suburbane unde terenul liber relativ ieftin abundă 
- A fi practic (sau a nu fi) în proiectarea de arhitectură - este un aspect esențial recunoscut pe piața globală - faptul că proiectul de diplomă este ultima șansă a studentului de a se exprima liber, fără buget fix, nu este o totală justificare în a aborda scheme nepractice, foarte largi, fără un program bine conturat, și fără grija unui virtual buget.

- Se observă cele menționate mai sus în soluțiile alese de rezolvare a programelor educative și de cercetare / dezvoltare care sunt normal abordate pragmatic integrând arhitectura cu tehnologia și cu peisajul locului (de cele mai multe ori ales ca să se juxtapună pe caracterul tehnic, steril impersonal al interiorului de laboratoare și al activității de mare concentrare, stress și exactitate care are loc în ele).

- Excesul de spațiu dedicat circulației scumpește investiția atât la execuția ei, cât și la exploatarea ei, - beneficiile fiind minore - este stiut că zonele de interacțiune între cercetători sunt acele alcoves special amplasate în locurile unde ei se adună natural cum ar fi coffee places, cantina, sala de exerciții, grădina cu sculpturi, săli de conferințe. Căile de circulații foarte lungi - adevarate promenade - devin nepractice și par că lucrează împotriva asocierii și colaborării între persoane, grupuri.

- Dar câte alte nevoi reale sunt uitate la clădirile de laboratoare de cercetare și dezvoltare? Prezența uriașă a spațiilor de utilități "serving functions" care poate depăsi ca mărime și cost pe cea de "served functions" - nu este exprimată clar. Și cum se îmbină ele armonios și economic? Lipsesc concepte de separare între părțile hazardoase (care există mai mult sau mai puțin în toate laboratoarele) și cele de cercetare nehazardoase cerute de protecția muncii și paza contra incendiilor.

- Lipsa unui program (tema de proiect, comanda socială, brief- în esență sunt identice -) din nou o sesizez. Nu cred că studentul este vinovat de lipsa unui program structurat și clar. În practica reală, noi primim un program, poate incomplet, dar destul ca să știm în ce direcție mergem. Sunt și cazuri unde arhitecții fac parte din colectivul de întocmire a unei note de comandă, sunt și cazuri în care tema lipsește cu desăvârșire, forțând proiectantul să-și formeze din imaginație și / sau din cultură un program pe care devine confortabil să-I realizeze pe hârtie. Nu asta este intenția la diplome după cum văd eu - programul și cerințele NU sunt cele stabilite de arhitect, sunt cele dorite de beneficiari, de public (comandă socială). În a răspunde corect și complet programului, arhitectul se informează, se educă în cele ce țin de activitatea beneficiarilor, foarte adânc trebuie învățat și stăpânit business-ul beneficiarului pentru un proiect reușit. Intrăm aici în conceptul de "building specialization" care este un alt subiect pentru altă ocazie.

- Alte domenii în afara arhitecturii participă la proiect și astfel el se conturează de multe ori diferit de imaginea pre-concepută a arhitectului. Balansarea acestor forțe în procesul de proiectare, orchestrate de un proiectant versat în toate domeniile implicate, este reușita unui proiect. De aceea numim proiectarea o activitate de echipă. 
(english version)

I'm writing late, but I assure you that the memories of the March 2019 diploma session are still vivid in my memory. It is the third invitation, and second invitation to write this article - all due to the initiative of President E.B. Popescu to have among the critics of the school and some guests who practice the profession abroad. All I write are personal opinions formed during the 45 years of the global practice of the profession plus short academic activities both in Mincu and in the USA. The practice of architecture in the USA is regulated by the State where you practice - mine being New Jersey (NJ) which is very strict in issuing and renewing the right of signature - that being said, those who practice in NJ participate annually in numerous educational events in matter, many of them being in architecture schools - in my case Princeton Univ. Thus, the connection between the practice and the academy so necessary to our profession is real in my case.

I find that the initiative of the President in this direction is good for the students of UAUIM, in that it exposes them to the experience of being evaluated and from a global point of view, not only locally. The discussion of merit or not of this system is long and complex, I will approach it on another occasion.

The reality is that our practice has been global for at least 30 years and history reminds us that it is not a unique phenomenon of the 20-21 century. Clearly in ancient times the architectural form and the materials / systems of construction have circulated of course in a restricted area for obvious reasons.

Through the course of history, the territory expanded in the Middle Ages to cover most of civilized Europe, then the industrial revolution expanded the circulation area of the architecture over the Ocean, in modernity it spread throughout the American continent, in the post-modernity period we expanded to cover everything the continents with remarkable presence in many metropolises of the world. I can say that at a high professional level, borders do not exist in our profession.

Talented practitioners from different countries and cultures design and build in remote and geographic and cultural places from their "home" training - this is what globalization has brought us. Most recently I see that talented practitioners from the countries of Africa are also starting to enter with major architectural works in some cities which are difficult to penetrate due to the quality and originality of the promoted architecture, such as USA, and West Europe. But the reverse of the medal exists and has for years been acknowledged and outlined as having a negative effect on societies, especially on environmental issues, consumerism, economic-social inequalities and lost cultural identity - this is a long discussion that I hope to have with another occasion. Ion Mincu School - as I see it - navigates between a strong regional tradition - rich historical-cultural and the contemporary global language of today's architecture.

In the diplomas discussed below, there are sporadic elements that concern the whole of humanity, such as climate change, security and safety of consumers and goods, urban agglomerations, high cost of energy, very difficult and expensive problem of population transport, accessibility of those with disabilities, energy conservation, in addition to adopting a language that will attract business, and to please the beneficiaries who pay the investment for a specific branding and profit as well as those who will use it and operate it. Of course the projects 
must also comply with the requirements of the local bodies of approval and control in the territory where it is being built. We can see clearly that the number of requirements is much higher now than it was decades ago, these coming over the short deadlines, the small budgets allocated and the global competition in which we profess. We are not surprised that these barriers squeeze the number of graduates willing to practice in a small number - that is, only those talented and passionate in school will be able to navigate this new market.

Not to be overlooked is the proven fact that the environment where a student is trained as a designer is important - the school where he spends many years literally days and nights, the city where he lives and runs daily. The radical modernist formation of most graduates from Chicago's IIT (Illinois Institue of Technology) is known as the powerful imprint left by Mies VanDer Rohe, if we compare it to a modernist poetic formation of schools in the US East (NY, Philadephia) influenced by theorists / post modernist practitioners (Luis Kahn, Robert Venturi, Michael Graves, etc.)

Recently, the notion that "authorship" in today's profession disappears from causes related to robotic technology of design and execution, that of globalization of the climatic notion, internationally accepted codes and global language of expression, is discussed and accepted in the US the authors become irrelevant, the social command taking their place as authority in the design decisions.

How do the above issues address (or fail to address) the diplomas from March 2019? By reading the article in the Arhitext 3/2018 magazine I see similar qualities / deficiencies in 2019 with those of 2018. will not repeat anything from the previous article - it exists and can be consulted as needed, so what are the new elements in 2019 in the following categories:

(Not listed in certain order, all are equally important)

- The answer to the project theme

- Site integration - context.

- Economic - the contribution that may (or may not have) be invested in raising welfare in the chosen area.

- Safety in operation - codes under construction

- The structural part, the mechanical - electrical part, the coordination between the disciplines

- The aesthetics and quality of life offered to the occupants

- Steps to protect natural resources and combat the causes that lead to climate change

- Of course the student's presentation, verbal, visual as well as his / her physical presence before the jury.

There is another category that I mention because it exists in the world and it has its role - namely, our talent in advocacy to politically support topics related to the job, with ramifications in the election campaigns of those who can support or hinder our goals - but I think that is not the case in Romania maybe I might be wrong here.

From the group of 16 diplomas presented for judgment and scoring, I find a consistency in the quality (or lack thereof) among students, nothing rises above average, and I have not noticed below average. As a common feature, the volume of work submitted is consistently huge at most of the presentations seen - the design work is indeed very laborious, but we often hear the slogan: "work smart not hard" - and I assure you that it is real and very indicated in American practice. It refers in particular to reaching the essential elements in the design, the 
ideas, the message, the innovation, leaving the graphics and modeling part of the robots to do it.

The diplomas presented can be considered as being in the "BoD" phase, ie "basis of designation", which represents about $30 \%$ of the total effort to complete a project execution. There is no need for more details in diplomas, the need is that at the end of a BoD all the design decisions will be correct / completely taken regarding all the design parameters, from the theme, to the site, to codes, costs, the construction mode, functionality. , coordination with engineering, aesthetics. This BoD in most cases develops towards design development / contract documents in other design offices, in other countries and on other continents, the continuity of ideas can be interrupted throughout, therefore the BoD must be as complete as possible, without ambiguity. if you wonder why this system? - There are complex economic and political reasons that are not part of this article.

Listening to the opinions of other professors invited from abroad to this court, I was surprised to hear similar opinions between us, which aim at improving diplomas - such as: the higher frequency of project corrections long before drawing the first line on CAD.

The foreign teachers, around a lunch table and in the presence of Mr. Decan and other teachers from the UAUIM stated that they are willing to do the "online correction" during the development of the diploma project. By mutual agreement it was found that there is a form of "internet review and discussion" at UAUIM, such as UAUIM sponsored websites on groups of students, managed by diploma advisers, and access to that site can be given to those consultants who volunteer to make checks of projects during the period allocated to diplomas. I am not informed if this process has been implemented, and with what results, of course I am among those who volunteer for this effort.

Without redesigning the project discussed, about what we see in the content of diplomas on paper on the material "handout" and what we hear from future architects students:

Addresses regarding the diplomas seen:

- Although artistic / cultural / educational themes abound at the point where you can ask yourself "where are the real needs of the country treated? themes of rehabilitation of some forgotten buildings and / or existing areas appear. They are present in many diplomas and this year - a meritorious thing that achieves economic, ecological, cultural values to preserve the country's valuable past. Messages of sustainable thinking, revitalization / lifting of the much desired degraded areas are present and remain appreciated under the current conditions in Romania. Most of the times, the approach scale of the volumetry of the project is appropriate with the theme, and with the chosen location, the argumentation of the formal and functional decisions most of the time find it well-outlined. I also find the ability of some to integrate the valuable vernacular language of the national peasant architecture with the themes, forms and contemporary language of architecture.

- I expect to appear in future diplomas and approaches / investigations of global issues, already real outside the borders, but with possible repercussions also in the country - now or later but will not go unnoticed. I am referring to global humanitarian issues related to migration, climate change with economic repercussions, poverty and lack of opportunities, lack of adequate housing, 
energy crisis in a world where access to energy at a convenient price is the key to development, excessive consumerism and pollution, access - or lack thereof - to information technology globally. These and similar topics should be supported with references to real-world progress that seeks to address today's social issues, such as: Smart City, Net Zero buildings, Live, work, play communities, etc.

- Acknowledged and accepted is that the above ideas are not sufficient for the success of a project - they are a good start that must be continued with less visible but equally or more important resolutions than the message of the project. I am referring here to the little attention paid to diplomas seen in building codes for safety in use, such as escape routes, separation into smoke / fire resistant compartments, - generally about what P118 refers to and I should not stress the importance his approval of a project. By rehabilitating a building of the 18th, 19th century, the security part in using a building must be completely restored to today's norms - it cannot remain as we find it in those periods.

- Equally important is the observance of the accessibility standards of those with disabilities maybe there is still no legislation in this regard in Romania, but it is in the whole world and you find your place in Romania for economic and political reasons within the EU., which is the subject of another discussion. I refer here in particular to those who have chosen to treat programs for the elderly where total accessibility is essentially attainable, or more elegantly said, "universal design for universal people".
- I can also say that the lack of deepening engineering considerations in constructions such as the mechanical and electrical parts still exists. The elevators need a mechanical pump room if it is hydraulic, or one of the electric motors in the penthouse if the cables are on traction.

- Alternative energy - (wind turbine, geothermal) appears in diplomas but is not conclusively developed with economic ROI (return of investment) calculations that prove to the beneficiary that they are a good investment for any lender, ROI being the single most important argument in favor of investments in alternative energies.

- Solar panels seem forgotten even though their technology is advancing year by year as their cost goes down. Accidentally and in isolation, l observe the concept of "green roof" - which has multiple positive effects on the environment, especially in cities, but also, without a convincing explanation of the benefit vs. cost.

- From the formalist point of view of the treatment of buildings I observe with pleasure that the method of design "inside-out" as opposed to "outside-in" are predominant in most all diplomas. These show clarity in the thinking of the future architect student and the recognition that there is a program, a structural system, a site, a budget that are priority to the form of expression.

- But when we think about the budget, at the cost of such a building we can be surprised by some selections of systems considered expensive - and not on the scale of the project, - such as: spaces too generous for traffic, the parking lot that requires elevators for cars, basements mechanics, 
for utilities and sub-grade garages in suburban areas where relatively cheap free land abounds.

- Being practical (or not being) in architectural design - it is an essential aspect recognized on the global market - the fact that the diploma project is the last chance of the student to express himself freely, without a fixed budget is not a full justification it addresses impractical, very broad schemes, without a well-defined program, and without the care of a virtual budget.

- The above mentioned ones are observed in the chosen solutions for solving the educational and research / development programs which are normally pragmatically approached, integrating the architecture with the technology and the landscape of the place (most often chosen to be juxtaposed with the technical, impersonal sterile character. of the interior of laboratories and of the activity of high concentration, stress and accuracy that takes place in them)

- Excessive space dedicated to circulation increases investment in both its execution and its exploitation - the benefits being minor - it is known that the areas of interaction between researchers are those alcoves specially located in places where they naturally gather such as coffee places, canteen, exercise room, sculpture garden, conference rooms. The very long roads - real walks - become impractical and seem to work against the association and collaboration between individuals, groups.

- But how many other real needs are overlooked in the buildings of R\&D laboratories? The huge presence of utility functions that can exceed the size and cost of "served functions" - is not clearly expressed. And how do they combine harmoniously and economically? Concepts of separation between hazardous parts (which exist more or less in all laboratories) and non-hazardous research required by labor protection and fire protection are missing.

- The lack of a program (project theme, social order, brief) - they are essentially identical - again I notice it. I do not think that the student is guilty of the lack of a structured and clear program. In actual practice, we receive a program, perhaps incomplete, but enough to know in which direction we are going. There are also cases where the architects are part of the collective for drawing up a command note, there are also cases where the theme is completely missing, forcing the designer to form out of imagination and / or culture a program that becomes comfortable to carry out. on the paper. This is not the intention for diplomas as I see it - the program (requirements) are NOT those set by the architect, are those desired by the beneficiaries, by the public (social order). In responding correctly and completely to the program, the architect is informed, educated regarding the activity of the beneficiaries, very deep must learn and master the busines of the beneficiary for a successful project. We enter here in the concept of "building specialization" which is another topic for another occasion.

- Other areas outside the architecture participate in the project and thus it is often outlined differently from the architect's pre-conceived image. Balancing these forces in the design process, orchestrated by a designer versed in all areas involved, is the success of a project. That's why we call designing a team activity. 
Citare articol curent / Citation:

(Ro)

Perciali M. (2021). Discuții pe marginea diplomelor de la Facultatea de Arhitectură, Sesiunea martie 2019 UAUIM. în Teoria proiectului de arhitectură. Idei construite. SP FA UAUIM.

EUIM - Editura Universitară lon Mincu, București.

(En)

Perciali M. (2021). Discussions on the diploma projects from the Faculty of Architecture, 2019 March (Diploma Session) UAUIM. in Architectural design theory. Built ideas. SP FA UAUIM. EUIM Ion Mincu University Publishing House, Bucharest. 